\title{
SISTEM PEMICU EXCELLENT KARYAWAN PADA KANTOR KEMENTRIAN HUKUM DAN HAM SUMATERA UTARA
}

\author{
Ahmad Zakir ${ }^{1)}$, Maulida Sri Putri ${ }^{2)}$, Yulia Agustina Dalimunnthe ${ }^{3)}$, Tantri Hidayanti Sinaga ${ }^{4)}$ \\ 1,2,3,4 Fakultas Teknik Dan Komputer, Universitas Harapan Medan \\ email: suratzakir@gmail.com, maulidasriputri07@gmail.com, yulia.agustinadlm@gmail.com, \\ tantri.hida83@gmail.com
}

\begin{abstract}
In this system, the company is currently developing many ways by the company to do the assessment in a computerized way. companies are required to follow business competition so companies must develop human resources with their respective supervisors or directors. Trigger employee evaluation is one of the techniques that will be applied so as to provide information to superiors to reward the quality of human resources who have done a good job. This research will develop a superior company trigger system using Android-based media. The system implemented can be used by superiors to determine the best employees in accordance with the value of the work performed by each employee. The purpose of this research is to study and develop the system that is currently running in order to become even better at doing employees. The results of this study include android-based applications in conducting employee talks that can facilitate superiors.
\end{abstract}

Keywords: Overview, Employees, Android, Company, Trigger

\section{PENDAHULUAN}

Penilaian kinerja adalah tinjauan formal dan evaluasi kinerja individu [1]. Penilaian kinerja adalah mengevaluasi kinerja relatif karyawan saat ini dan dimasa lalu terhadap standar prestasinya. Jadi dapat disimpulkan bahwa penilaian kinerja adalah evaluasi seorang individu atau karyawan selama ia bekerja dalam sebuah organisasi atau perusahaan [2], [3].

Kepuasan karyawan dan excellent karyawan adalah dua hal yang saling berkaitan. Seorang karyawan yang baik adalah karyawan yang puas dengan excellentnya sendiri. Faktor yang paling dominan menciptakan karyawan yang excellent adalah dari dalam personalnya sendiri dan juga faktor masukan dari sekeliling [4]. Faktor sekeliling disebuah perusahaan yaitu manajer atau atasan, bawahan, anggota tim dan pelanggan internal atau eksternal.

Pada Kantor Kementrian Hukum dan HAM Sumatera Utara sudah diterapkan penilaian excellent pegawai melalui pembuatan surat edaran, penilaian excellent pegawai oleh atasan masing-masing. Penilaian excellent pegawai masih dilakukan secara manual dan tidak terorganisir. Hal ini mengakibatkan kurang rincinya penilaian excellent dari masing-masing karyawan. Penilaian atasan yang tidak akurat karena ketersediaan waktu atasan yang minim untuk melakukan penilaian manual, pemberkasan penilaian yang tidak serentak karena pengembalian berkas yang tidak bersamaan. Pada penelitian sebelumnya [5], [6], tentang pengaruh penilaian kinerja terhadap kepuasan kerja dan prestasi kerja. Pada penelitian ini Januari mendapatkan hasil penilaian kinerja berpengaruh secara signifikan terhadap kepuasan kerja sebesar $88,5 \%$.

Akses penilaian yang mudah dan cepat sangat berpengaruh terhadap nilai excellent pegawai. Akses akan mudah jika ter manajemen. Sistem informasi merupakan suatu sistem di dalam suatu organisasi yang mempertemukan kebutuhan pengolahan transaksi harian yang mendukung fungsi organisasi yang bersifat manajerial dalam kegiatan strategi dari suatu organisasi untuk dapat menyediakan kepada pihak luar tertentu dengan laporan-laporan yang diperlukan [7], [8], [9]-[14]. Pada paparan di atas penulis ingin merancang atau membangun Sistem Pemicu Excellent Pegawai Pada Kantor Kementrian Hukum dan HAM Sumatera Utara. Metode yang digunakan untuk pengembangan sistem yaitu dengan model waterfall dengan alat dan bahan pengembangan memakai usecase, activity diagram, bahasa program PHP, 
dreamweaver dan $M y S Q L$ sebagai basis data. Untuk item penilaian berdasarkan metode penilaian umpan balik 360-derajat meliputi masukan evaluasi dari banyak bagian yaitu atasan, bawahan, anggota tim.

\section{METODE PENELITIAN}

Adapun tahapan penelitian yang dilakukan dalam menyelesaikan perancangan ini adalah dengan melakukan perancangan menggunakan pemodelan UML (Unified Modelling Language) sehingga dapat memudahkan dalam penerapan sistem. Pemodelan sistem dilakukan dengan metode berorientasi obyek dengan menggunakan standarisasi UML, dengan tahap-tahap penentuan siapa saja actor yang terlibat dan perancangan use case specification, Interaksi diagram (sequence diagram). Perancangan pemodelan UML terdiri dari :

a. Use case

Use case diagram digunakan untuk mendefinisikan persyaratan fungsional dari sistem. Untuk menggambarkan interaksi antara user dengan sistem, dapat dilihat pada gambar use case diagram berikut ini :

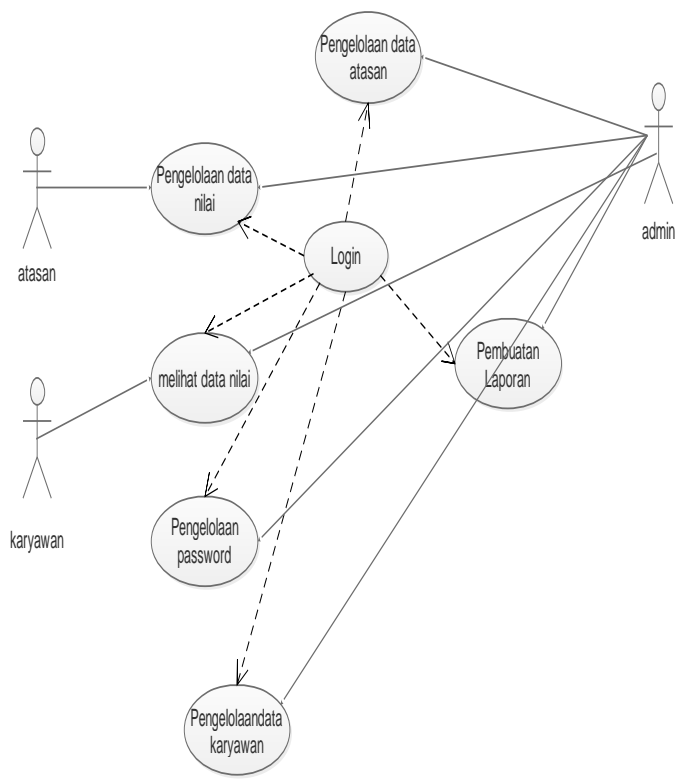

Gambar 1. Use Case Diagram

b. Activity diagram login user

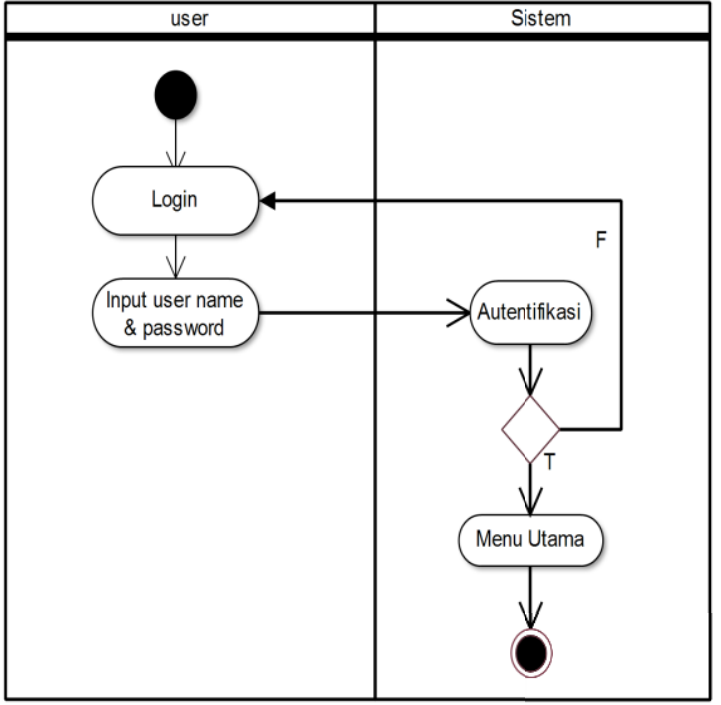

Gambar 2. Activity Diagram Login User

c. Activity diagram input data karyawan

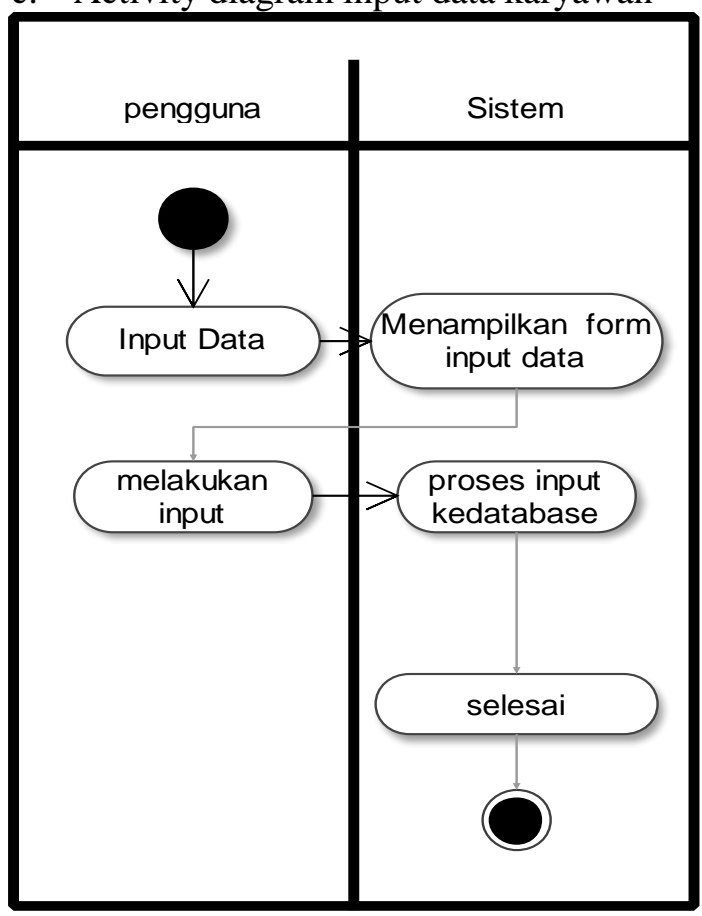

Gambar 3. Activity Diagram Input Data Karyawan

Keterangan gambar 3 pada menu input data pengguna dapat memasukan karyawan sesuai yang dibutuhkan, kemudian memasukan nama karyawan atau pegawai sehingga dapat dilakukan proses penambahan karyawan 


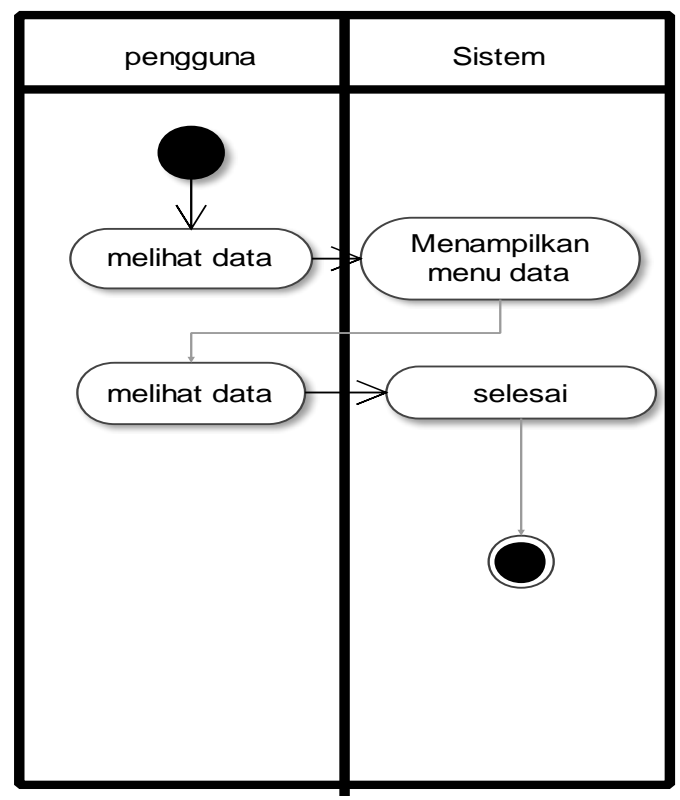

Gambar 4. Activity Diagram

Pada gambar 4 akan dijelaskan aktivitas dalam melihat data pada sistem yang akan dilakukan oleh pengguna, pengguna dapat melakukan melihat data dengan cara memilih menu lihat data kemudian sistem akan melakukan proses membuka tampilan menu data.

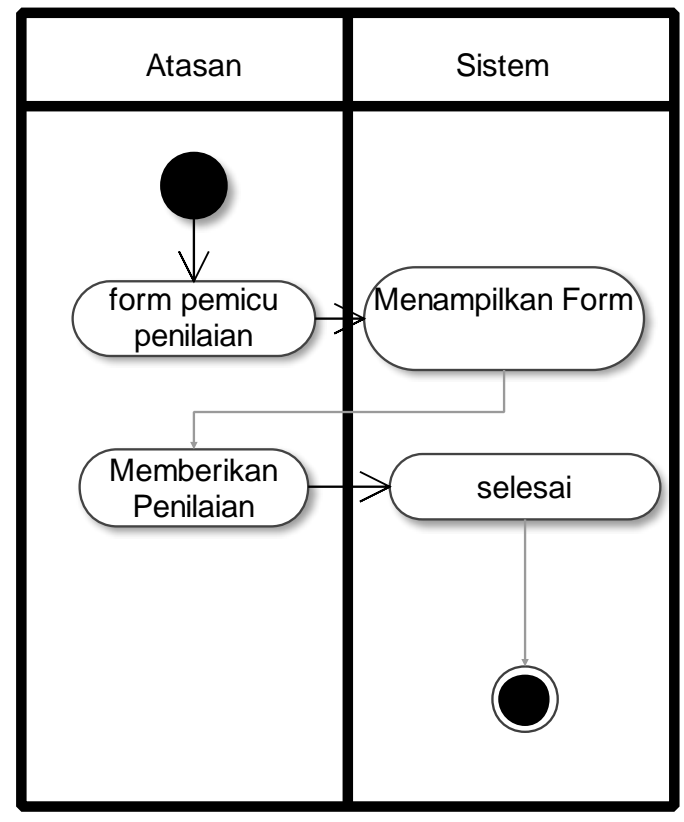

Gambar 5 Activity Diagram pemicu penilaian

Keterangan gambar 5 pada activity diagram pemicu penilaian berfungsi untuk melakukan penilaian terhadap karyawan oleh atasan berdasarkan aktivitas yang dilakukan oleh karyawan.

\section{d. Sequence Diagram Login Admin}

Sequence Diagram Login Admin menggambarkan prosedur informasi login yang dilakukan oleh admin untuk masuk kehalaman utama menu admin, yang mempunyai hak akses untuk menambah, merubah, dan menghapus data pada sistem. Sequence Diagram Login Admin yang dirancang dapat dilihat pada gambar 6 .

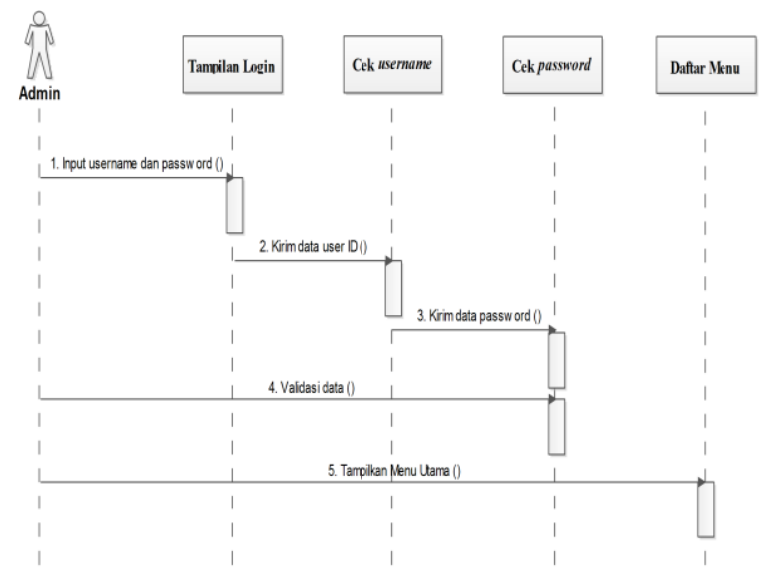

Gambar 6 Sequence Diagram Login Admin Sequence Diagram Login Admin diatas menjelaskan proses login yang dilakukan oleh aktor admin. Admin melakukan login dengan memasukkan username dan password pada form login. Sistem akan melakukan verifikasi atau pengecekan data ke dalam database apakah username dan password sudah benar. Apabila verifikasi gagal, maka sistem akan menampilkan pesan gagal. Sebaliknya, apabila verifikasi berhasil, maka sistem akan menampilkan halaman menu utama admin.

\section{e. Sequence Diagram Menu Utama}

Layanan user dimulai ketika user melakukan login kedalam sistem, sehingga sistem menampilkan daftar menu seperti form penilaian dan daftar karyawan. Semua menu yang tersedia tedapat pada sistem ayang berfungsi sebagai pengolah data sesuai kebutuhanSequence Diagram Menu Utama menggambarkan prosedur kerja oleh pengguna, dapat lihat pada gambar 7 . 


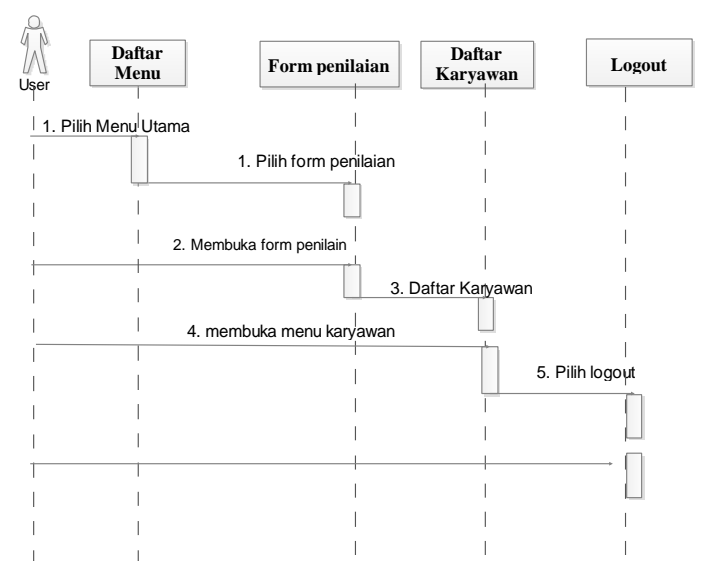

Gambar 7 Sequence Diagram Menu Utama use

f. Sequence Diagram Menu Admin

Sequence diagram menu admin yang penulis rancang dapat dilihat pada Gambar 8.

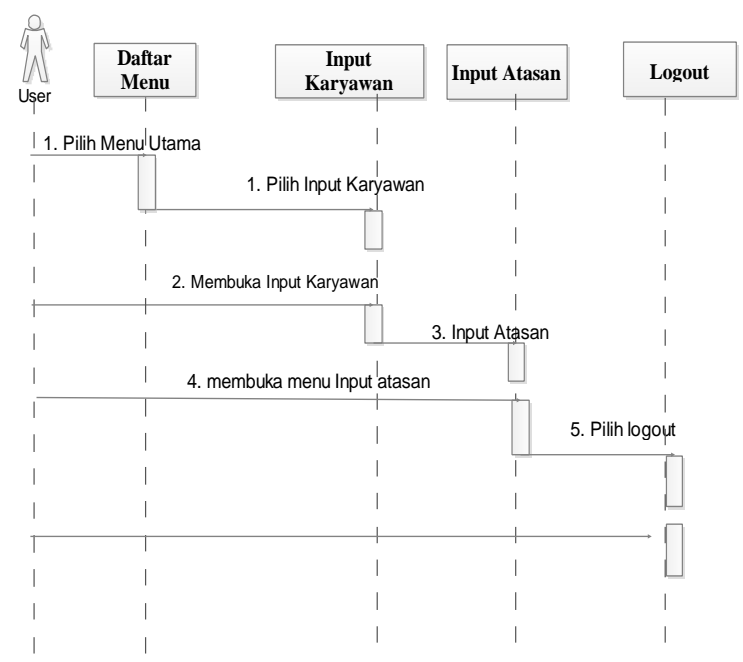

Gambar 8. Sequence Diagram Menu admin

Keterangan gambar 8 akan menjelaskan cara kerja administrator yang berfungsi sebagai pengolah data yang dapat melakukan penambahan data dan penghapusan data sesuai kebutuhan

\section{g. Deployment Diagram}

Salah satu jenis alat atau bahasa (UML) yang digunakan untuk memvisualisasikan, menspesifikasikan, dan mendokumentasikan proses yang terjadi pada suatu sistem perangkat lunak berbasis Object Oriented yang akan dibangun. Berikut ini adalah deployment diagram system.

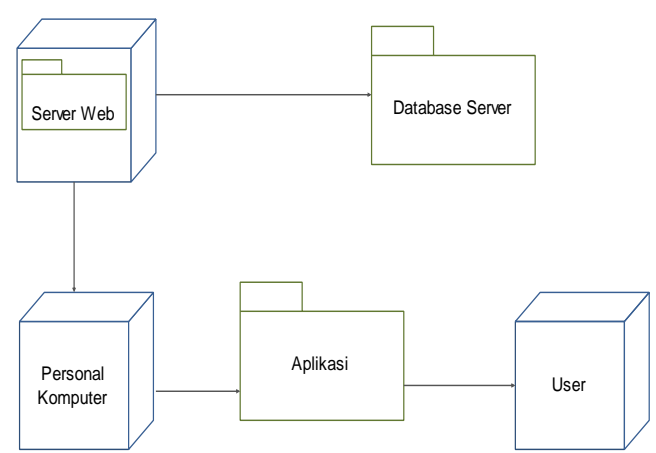

Gambar 9. Deployment Diagram

\section{HASIL DAN PEMBAHASAN}

Pada bab ini dilakukan implementasi dan pengujian terhadap sistem. Tahapan ini dilakukan setelah perancangan selesai dilakukan dan selanjutnya akan diimplementasikan pada bahasa pemrograman.

Setelah diimplementasikan maka dilakukan pengujian terhadap sistem dan dilihat kekurangan-kekurangan pada aplikasi untuk pengembangan sistem selanjutnya. Pada penelitian ini dalam mengembangkan suatu sistem pemicu excellent terhadap penilaian kinerja karyawan berbasis android yang bertujuan untuk menentukan pemicu penilaian karyawan yang dapat memberikan gambaran kepada atasan untuk memberikan prestasi terhadap karyawan.

Setelah sistem dianalisis dan didesain secara rinci, maka selanjutnya dilakukan tahap implementasi. Implementasi merupakan tahap meletakkan sistem sehingga siap untuk dioperasikan. Implementasi bertujuan untuk melaksanakan perancangan perancangan yang telah dibuat sehinga pengguna dapat memberikan masukan kepada pembangun ataupun pengembang sistem sistem.

a. Tampilan Menu Login administrator

Pada menu login administrator pada Sistem terdapat form username dan password, username ialah id admin yang sudah terdaftar didalam database, username juga merupakan identitas yang tidak ada duanya dalam sebuah aplikasi jika sudah mengguna id tertentu saat mendaftar pada sebuah aplikasi maka orang lain tidak dapat mendaftar dengan id yang sama. Seperti pada gambar berikut ini: 


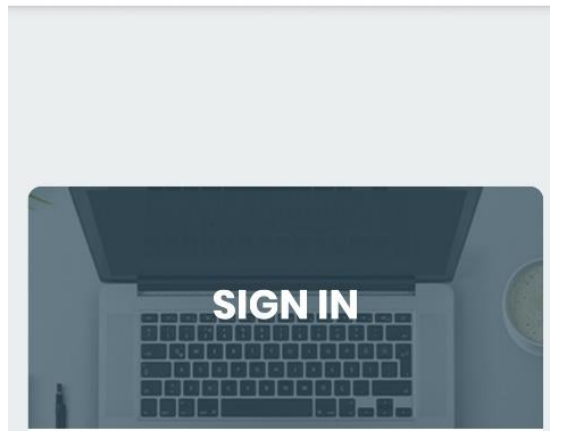

c. Tampilan Menu data karyawan

Tampilan menu data karyawan akanmenampilkan data karyawan yang diperlukan dalam melakukan penilaian sehingga dapat dijadikan pemicu excellent, berikut ini adalah tampilan menu data karyawan yang sudah siap diimplementasikan, lihat pada Gambar 12.

\section{Username \\ Enter username}

Password

Enter password

\section{Login}

Gambar 10. Tampilan Menu login sistem

b. Tampilan Menu Utama administrator

Tampilan menu utama akanmenampilkan semua menu yang ada pada sistem pemicu excellent terhadap penilaian kinerja karyawan berbasis android. pada sistem ini akan menampilkan menu menu seperti dashboard, data atasan, data karyawan, data nilai,. Berikut ini adalah tampilan menu utama yang sudah siap diimplementasikan, lihat pada Gambar 11.

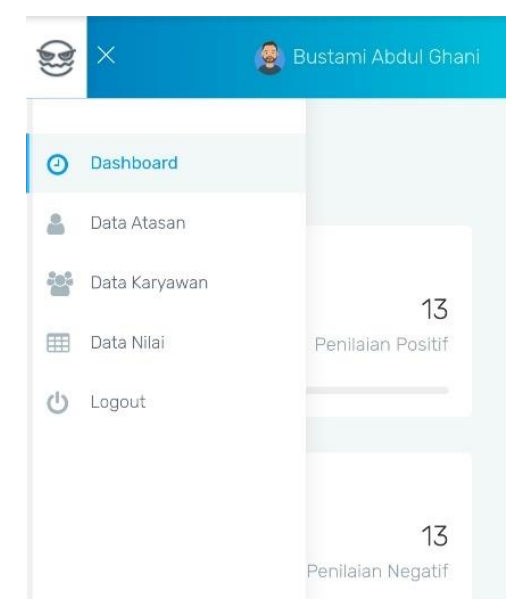

Gambar 11Tampilan Menu Utama

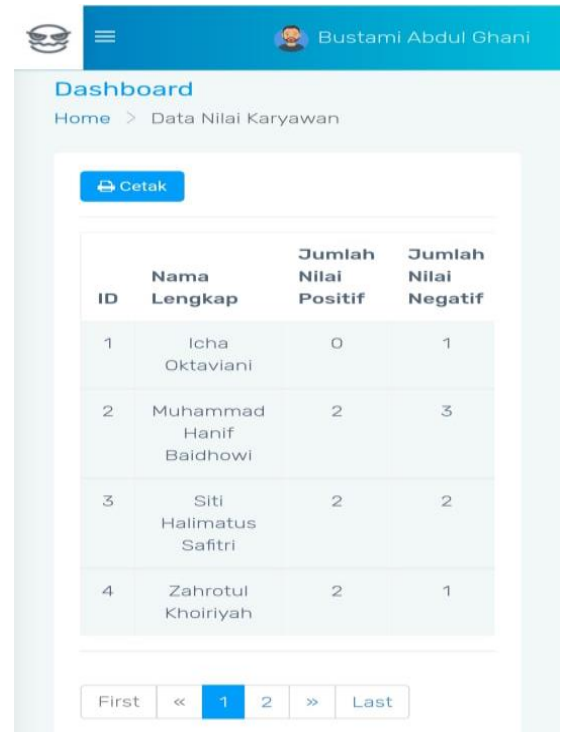

Gambar 12. Tampilan Menu data karyawan

d. Tampilan Menu tambah data karyawan

Tampilan menu tambah data karyawan akanmenampilkan form untuk melakukan penambahan data karyawan yang diperlukan, berikut ini adalah tampilan menu tambah data karyawan yang sudah siap diimplementasikan, lihat pada Gambar 13.

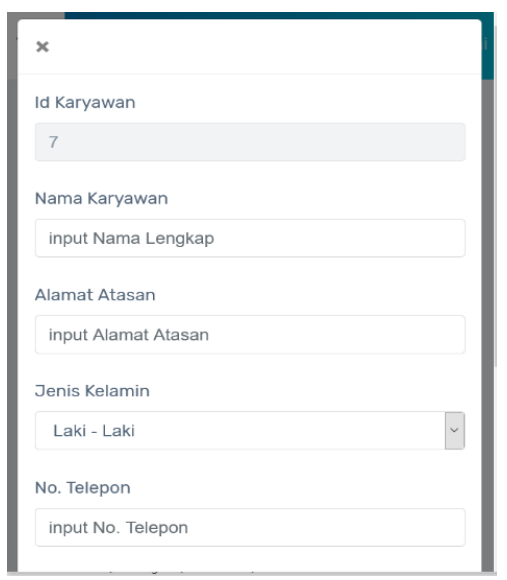

Gambar 13. Menu tambah data karyawan 
e. Tampilan Menu tambah data atasan

Tampilan menu tambah data atasanakanmenampilkan form untuk melakukan penambahan data atasan yang diperlukan, berikut ini adalah tampilan menu tambah data atasan yang sudah siap diimplementasikan, dapat dilihat pada Gambar 14.

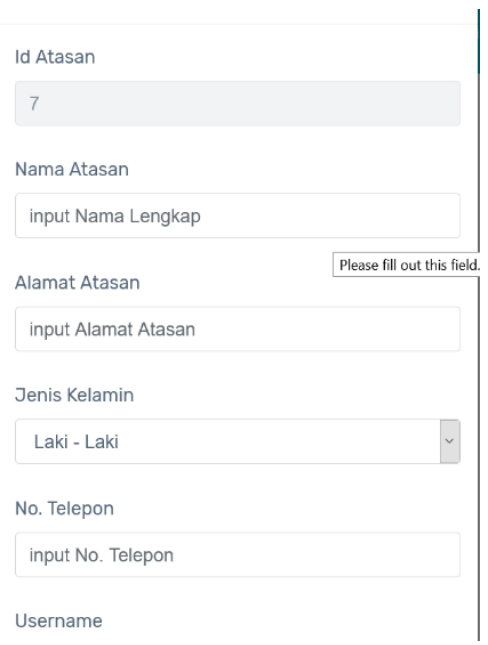

Gambar 14. Menu Tambah Data Atasan

f. Tampilan Menu data penilaian

Tampilan menu data penilaian akanmenampilkan semua data penilaian yang sudah dilakukan oleh atasan padasistem pemicu excellent terhadap penilaian kinerja karyawan berbasis android. Berikut ini tampilan menu data penilaian, dapat dilihat pada Gambar 15.

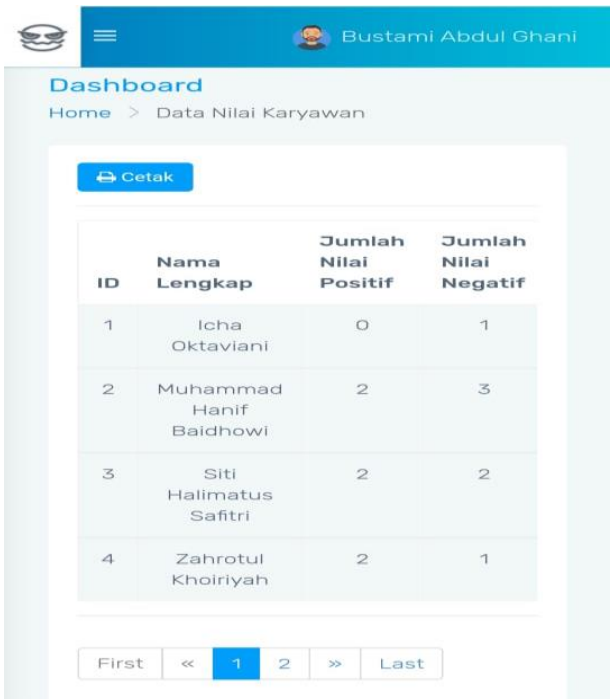

Gambar 15. Tampilan Data Penilaian g. Tampilan Menu Utama atasan

Tampilan menu utama atasan akanmenampilkan semua menu atasan yang ada pada sistem pemicu excellent terhadap penilaian kinerja karyawan berbasis android. pada sistem ini akan menampilkan menu menu seperti dashboard, data karyawan, input penilaian, dan ganti password. Berikut ini adalah tampilan menu utama atasan yang sudah siap diimplementasikan, lihat pada Gambar 16.

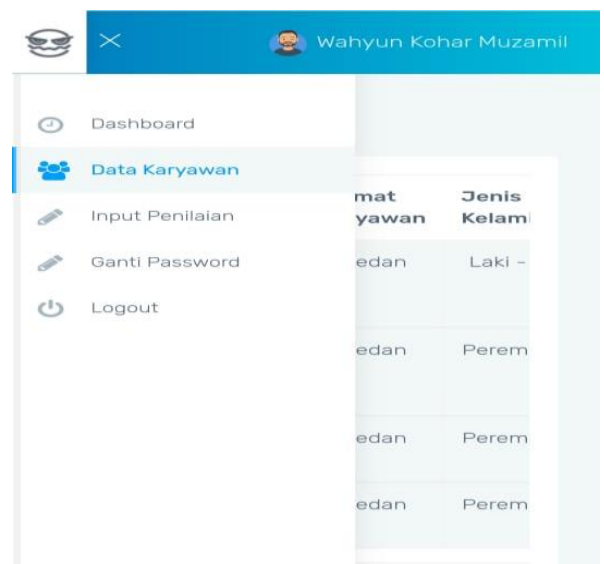

Gambar 16. Tampilan Menu Utama

h. Tampilan Menu form penilaian karyawan

Tampilan menu form penilaian karyawan akanmenampilkan semua data karyawan yang ada pada sistem pemicu excellent terhadap penilaian kinerja karyawan berbasis android. Kemudian atasan dapat memilih karyawan mana yang akan diberi penilaian, penialaian ada dua form ada penilaian negative dan positif. Berikut ini adalah tampilan menu form penilaian karyawan yang sudah siap diimplementasikan, lihat pada Gambar 17.

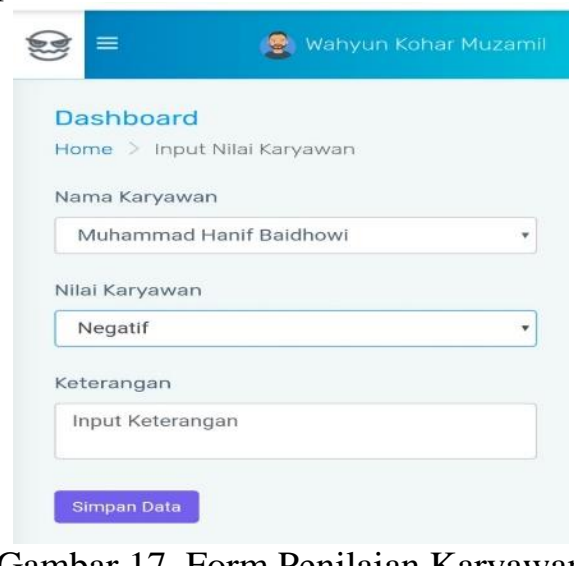

Gambar 17. Form Penilaian Karyawan 
i. Tampilan Menu data hasil penilaian karyawan

Tampilan menu data hasil penilaian karyawan akanmenampilkan semua data penilaian yang ada pada sistem pemicu excellent terhadap penilaian kinerja karyawan berbasis android. Berikut ini adalah tampilan menu data hasil penilaian karyawan yang sudah siap diimplementasikan, lihat pada Gambar 18.

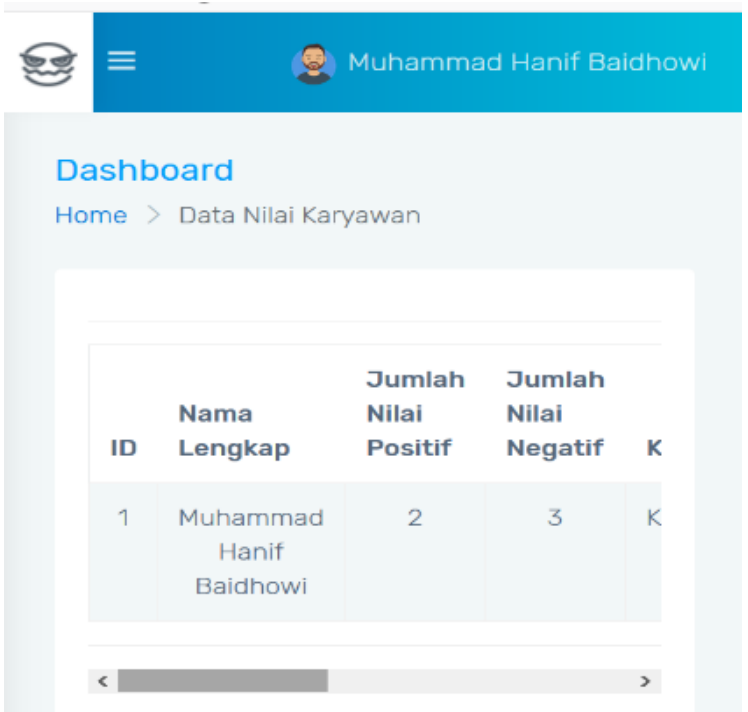

Gambar 18. Tampilan Menu data hasil penilaian

\section{KESIMPULAN}

Dalam uraian rangkaian mulai dari proses sistem pemicu excellent terhadap penilaian kinerja karyawan berbasis android yang bertujuan, dapat ditarik beberapa kesimpulan penting antara lain:

1. Untuk menentukan pemicu penilaian karyawan yang dapat memberikan gambaran kepada atasan untuk memberikan prestasi terhadap karyawan

2. Setiap karyawan dapat mengetahui penilaian yang diberikan oleh atasan sehingga dapat memperbaiki kinerja sesuai dengan deskripsi pekerjaannya

\section{REFERENSI}

[1] Saefudin and S. Wahyuningsih, "Sistem Pendukung Keputusan Untuk Penilaian Kinerja Pegawai Menggunakan Metode Analytical Hierarchy Process (Ahp) Pada RSUD Serang," J. Sist. Inf., vol. 1, no. 1, p. 33, 2016.

[2] T. Ernawati and J. Endrawan, "Peningkatan Kinerja Jaringan Komputer dengan Border Gateway Protocol (BGP) dan Dynamic Routing (Studi Kasus PT Estiko Ramanda)," Khazanah Inform. J. Ilmu Komput. dan Inform., vol. 4, no. 1, p. 35, 2018.

[3] N. Akbar, "Pengukuran Kinerja Perusahaan Jasa Dengan Pendekatan Balanced Scorecard Pada Pt . Pandu Siwi Sentosa Oleh Nicky Akbar Program Sarjana Alih Jenis Manajemen," 2011.

[4] R. F. Gerson, Mengukur Kepuasan Pelanggan: Panduan Menciptakan Pelayanan Bermutu. Jakarta: PPM, 2010.

[5] A. K. Hidayah, "Sistem Pendukung Keputusan Pemilihan Ketua Badan Eksekutif Mahasiswa Dengan Metode Simple Additive Weighting," JSAI (Journal Sci. Appl. Informatics), vol. 2, no. 1, pp. 92-96, 2019.

[6] maya sari, "ANALISIS BALANCED

SCORECARD SEBAGAI ALAT

PENGUKURAN KINERJA

PERUSAHAAN PT. JAMSOSTEK CABANG BELAWAN.," vol. 15, no. 1, pp. 52-64, 2015.

[7] L. T. Tombilayuk, R. Jumardi, and M. Maghfirah, "Evaluasi Kinerja Implementasi Sistem Informasi Perpustakaan Menggunakan Model Task Technology Fit," J. Technopreneursh. Inf. Syst., vol. 1, no. 3, pp. 68-73, 2019.

[8] L. Yulianti, H. L. Sari, and B. H. Hayadi, "Sutabri," Sist. pendukung keputusan peserta KB teladan di BKKBN Bengkulu menggunakan pemograman Vis. Basic 6.0, vol. 8, no. 1, p. 1, 2015.

[9] J. Simatupang and S. Sianturi, "PERANCANGAN SISTEM INFORMASI PEMESANAN TIKET BUS PADA PO. HANDOYO BERBASIS ONLINE," J. Intra Tech, vol. 3, no. 2, pp. 11-25, 2019.

[10] V. Sihombing and G. J. Yanris, "PENERAPAN APLIKASI DALAM MENGOLAH ASET DESA (STUDI KASUS: KEPENGHULUAN SRI KAYANGAN)," J. Mantik Penusa, vol. 4, no. 1, pp. 12-15, 2020. 
[11] V. Sihombing, "Aplikasi Simade (Sistem Informasi Manajemen Desa) Dalam Meningkatkan Pelayanan Administrasi di Kepenghuluan Bakti Makmur Kecamatan Bagan Sinembah Kab. Rokan Hilir Riau," SISTEMASI, vol. 7, no. September, pp. 292-297, 2018.

[12] J. Simatupang, "Perancangan Sistem Inventori Barang pada Toko Nichos Jaya Menggunakan Metode FIFO," J. Intra Tech, vol. 1, no. 1, pp. 31-42, 2017.

[13] V. Sihombing, "Sistem Informasi Penjualan Mobil Suzuki Di Dealer Bagan Batu," SISTEMASI, vol. 7, no. 2, pp. 113-119, 2018.

[14] A. Ardian, I. Purnama, and V. Sihombing, "Perancangan Aplikasi Pengolah Data Siswa Berbasis Android (Studi Kasus : Mis Nurul Huda Labuhan Batu Selatan)," Pengabdi. Masy. Ika Bina En Pabolo, vol. 1, no. 1, pp. 40-53, 2019. 